\section{Unlawful entry}

MORE than one in five Californians were born in other countries: many of the rest were born to foreign-born parents. Since its foundation, California has derived much of its economic (and scientific) strength from the vigour of its foreignborn residents. Thanks to its immigrants, this one state is proud to have the eighth largest economy on the world, with an aggregate personal income of around $\$ 650$ billion. But one can have too much of a good thing. Immigration, especially illegal immigration, is one of the three principal causes of California's current economic catastrophe: the others are the deep global recession and the downturn in defence spending. The first will solve itself, eventually; the second, which has particularly affected southern California, will shift after a certain amount of readjustment (see below). But even after the current recession ends, immigration will force State expenditure to outstrip income well into the next century

The first proposal for the budget for the next fiscal year, 1993-94, is that it will be balanced, at great sacrifice. There will be no tax increases, and across-the-board cuts any deeper than those already instituted will be detrimental: therefore, the budget reflects some hard choices. For example, job-creation schemes and K-12 (kindergarten to 12 th grade) education will assume top priority, but support for higher education will be cut by about 10 per cent. Ultimately, recovery depends on long-term economic restructuring rather than simply raising taxes and cutting spending, and there is no shortage of initiatives, some state-sponsored, to stimulate the economy.

Crucially, the budget is predicated on immediate injection of federal funds. The state's only solution is to hold its own citizens hostage to its demand that the federal government meets its obligations, and compensate California for its share of the federal immigration burden. If these funds are not forthcoming, further cuts will have to be made.

In the good old days, when California grew rich making fighter planes for Uncle Sam, the state received more in federal expenditure than it gave back in taxes. From a peak in $1982-83$ of $\$ 1.22$ federal input for every $\$ 1$ going out as federal taxes, the tables have now been turned so that by 1988 , the state was receiving just 91 cents for every dollar paid back in federal taxes. What with the federal budget deficit and the recession in general, this deficit is likely to widen still further. Indeed, it will be ripped wide open should the new administration cut defence spending further and target rich people for more taxes. In 1990, 12 per cent of all federal income tax returns came from California: but 16.5 per cent

of those returns declaring gross incomes of $\$ 100,000$ and above were filed from the Golden State. The governor has been labouring to close the gap, by lobbying for a large share of the $\$ 1.5$ billion federal defence conversion programme, but for the time being California will send more dollars to Washington than it gets in return.

Immigration will make the problem far, far worse. The United States as a whole has 20 million foreign-born residents, one-third of whom arrived between 1985 and 1990, and a quarter of whom live in California. The state will be obliged to provide healthcare and education to all these people as of right, while at the same time sustaining a relative decrease in the number of taxpayers.

Unfortunately for California, immigration policy is dictated from Washington, not Sacramento. The leaky borders are a federal responsibility, but federal law requires states to provide a variety of healthcare, child benefit and superannuation benefits to immigrants, legal or otherwise, without prospect of reimbursement from Washington. For example, $\$ 3.6$ billion of California's budget this year is being spent on K-12 education for illegal immigrants, or the citizen children of immigrants generally.

To make matters worse, the Federal Immigration Reform and Control Act

\title{
Women and children first
}

AT present there are approximately 250 million Americans, and 31.3 million (about 13 per cent, or one in eight) are Californians. Every year welcomes another 600,000 , and in the year 2000 there will be 36.4 million Californians, an increase of 6.4 million in the $1990 \mathrm{~s}$ (6.2 million in $1980 \mathrm{~s}$ ). But 2.5 million (39\%) of these people will be under 17 years old: the increase in this sector was 1.5 million in the 1980s. The taxpaying population (18-64 years), though, will grow more slowly in the 1990s than in the 1980s; 3.5 million compared with 4 million.

Natural increase (the number of births over deaths) will account for 55 per cent of this growth in the 1990s compared with 45 per cent in the 1980s: a decline in individual fecundity will be offset by a larger population of women of childbearing age (15-44 years); 8 million in 2000 compared with 7 million in 1990 .

Although natural increase will reduce the overall contribution of immigration from 55 per cent to 45 per cent of population growth in the 1990s, the percentage of immigrants from abroad will
(IRCA) of 1986 granted amnesty to illegal immigrants residing in the US since 1982. Under IRCA, Congress authorized $\$ 4$ billion of grants to help states assimilate their immigrants, but California received $\$ 467$ million less than the 60 per cent share to which it felt entitled. IRCA also required the US Attorney General to reimburse states for the cost of imprisoning illegal immigrant criminals. 12 per cent of Californian prisoners fall into this category, costing $\$ 243$ million annually, and Congress has appropriated not one cent.

In this way, California is paying heavily for an immigration policy imposed from above, something that it can no longer afford. In a bold political gamble, the governor has demanded - as part of the budget proposals - that Congress appropriates $\$ 1.5$ billion, no later than 15 May this year, to compensate California for the cost of assimilating its immigrants. Otherwise the budget will be in deficit before the 1993-94 fiscal year even begins.

If these funds are not received, the state will eliminate a variety of sensitive health and welfare programmes worth $\$ 1.2$ billion, and carve further huge chunks from its other programmes, confident that the federal government, not Sacramento, can be blamed. Higher education, subsidized to the tune of $\$ 4.7$ billion, is a tempting target. Give us the money, Bill, or we shoot this professor.

increase in spectacular fashion. In the 1980s, 18 per cent of the population growth was as a result of Americans moving to California from other states,

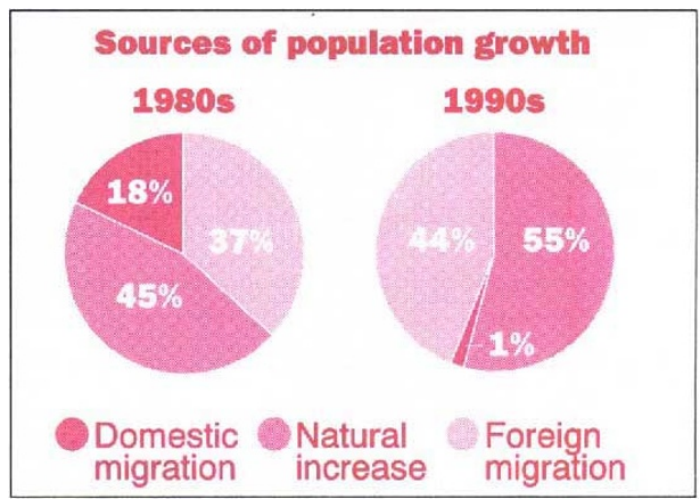

37 per cent from foreign immigration. In the 1990s, almost all immigration will be foreign: 44 per cent of the growth, compared with 1 per cent from domestic immigration. This sharp decline in domestic immigration may be related to the recession. In the year 2000 , a far higher proportion of Californians than today will be the children of immigrants from abroad, who will constitute a formidable drain on the state's resources. 